\title{
Utilização de uréia de liberação lenta em sal mineral na suplementação de bovinos de corte em pastagem de Tifton-85
}

\section{Use of slow release urea in the mineral supplementation of beef cattle Tifton-85 pasture}

\author{
Wagner Paris ${ }^{1 *}$; Renato Marchesan ${ }^{2}$; Paulo Emílio Fernandes Prohmann ${ }^{3}$; Luis \\ Fernando Glasenapp de Menezes ${ }^{1}$; Josinaldo Zanotti²; Diego Vicente Hartmann ${ }^{4}$
}

Resumo

O presente trabalho objetivou avaliar o efeito da suplementação com uréia de liberação lenta em substituição parcial da uréia comum, presente no sal proteinado de novilhas pastejando em capim Tifton-85 no período do inverno. O trabalho foi realizado no período de maio a setembro de 2010 , em uma área de 11,6 hectares de pastagem de Tifton-85 (Cynodon dactylon), dividida em quatro piquetes de 2,9 hectares. Foram mantidas 36 novilhas testers ( $1 / 2$ Red Angus $1 / 2$ Nelore), submetidas aos seguintes tratamentos: apenas sal mineralizado (SM); sal proteinado com uréia (SP); sal proteinado com $25 \%$ de substituição da uréia por uréia de lenta degradação (SPLD25); e sal proteinado com $50 \%$ de substituição da uréia por uréia de lenta degradação (SPLD50). Não houve efeito das diferentes fontes de suplementação sobre o desempenho dos animais $(\mathrm{P}>0,05)$, sendo recomendado a utilização de sal mineralizado que apresenta menor custo.

Palavras-chave: Forragem, nitrogênio não protéico, nutrição animal

\begin{abstract}
The present work to evaluate the effect of supplementation of urea release slow partial substitution of urea present in the common protein salt of heifers grazin Tifton- 85 during the winter. The study was conducted in the period from May to September 2010. In an area of 11.6 hectares of grazing Tifton- 85 (Cynodon dactylon), divided into four paddocks of 2.9 hectares, 36 heifers were kept testers $(1 / 2$ Red Angus $1 / 2$ Nellore), treated as follows: Only mineralized salt (SM) protein salt with urea (SP); protein salt with $25 \%$ substitution of urea by slow degradation of urea (SPLD25) and protein salt with $50 \%$ substitution of urea by slow degradation of urea (SPLD50). There wasn't effect of different sources of supplementation on animal performance $(\mathrm{P}>0.05)$, and recommended the use mineral salt that has lower cost.
\end{abstract}

Key words: Forage, non-protein nitrogen, animal nutrition

\footnotetext{
${ }^{1}$ Prof. Dr., Universidade Tecnológica Federal do Paraná, UTFPR-DV, Campus Dois Vizinhos, Dois Vizinhos, PR. E-mail: wagparis@yahoo.com.br; lfgdm@yahoo.com.br

2 Discente(s) de Mestrado do Programa de Pós Graduação em Zootecnia, UTFPR-DV, Campus Dois Vizinhos, Dois Vizinhos, PR. E-mail: renatomarchesan@yahoo.com.br; josinaldozanotti@yahoo.com

3 Prof. Dr. Centro Universitário de Maringá. CESUMAR, Maringá, PR. E-mail: pauloprohmann@yahoo.com.br

${ }^{4}$ Zootecnista, Terra Desenvolvimento Agropecuário, Maringá, PR. E-mail: diego.hartmann@zootecnista.com.br

* Autor para correspondência 


\section{Introdução}

A pecuária de corte brasileira, mesmo com muitas dificuldades, vem sofrendo anualmente mudanças significativas, abandonando lentamente o sistema tradicional de produção e adotando novas tecnologias que visam aumentar a eficiência no setor. Os avanços tecnológicos disponíveis, atualmente, permitem a redução na idade ao abate dos animais, sendo este um fator de impacto positivo no sistema produtivo. Com a diminuição do tempo de permanência dos animais na propriedade, o giro de capital é mais rápido, aumenta-se a taxa de desfrute do rebanho, produzindo carcaças de maior qualidade, que atendam a demanda de um mercado cada vez mais exigente.

O Brasil é o maior exportador de carne bovina do mundo e, além disso, está localizado em uma região tropical, com alto potencial para produção forrageira. Porém possui períodos de elevada e baixa produção, assim como sua qualidade nutricional. Dessa forma surgem períodos de ganho de peso intercalados por períodos de perda (MOREIRA et al., 2003), então algumas ferramentas tecnológicas disponibilizadas podem ser utilizadas dependendo de cada situação. Dentre as ferramentas disponíveis, a suplementação em pastagem se destaca com o objetivo de suprir a deficiência de nutrientes das forragens e também manter a taxa de lotação em períodos de baixa produção de matéria seca.

Nas condições tropicais, geralmente o teor de proteína bruta das pastagens, durante o período seco, fica inferior a 7\%. Quando a dieta não fornece esse nível mínimo de proteína bruta (PB) na matéria seca, a reciclagem da uréia não é suficiente para atender a demanda de nitrogênio pelos microrganismos do rúmen, resultando na queda do consumo e na digestibilidade da forragem (VAN SOEST, 1994). Dessa forma, a suplementação protéica tem por finalidade suprir a deficiência de $\mathrm{PB}$ proporcionando melhor desempenho animal.
A suplementação protéica para animais em pastagem tem sido utilizada no período em que há baixa produção de matéria seca, com o objetivo de aumentar o seu consumo e sua digestibilidade, melhorando o desempenho animal (EUCLIDES et al., 2001). Os principais efeitos da suplementação protéica estão relacionados às melhorias na eficiência da fermentação ruminal, velocidade de degradação ruminal da fibra e no consumo de volumoso (KNORR et al., 2005).

Os bovinos apresentam pastejo seletivo, com consumo maior de folhas e colmos verdes e baixo consumo de material morto. Durante o final do período das águas, pastagens em manejo contínuo podem apresentar baixa disponibilidade de folhas e baixo teor de PB. Portanto, o consumo de outras fontes de nitrogênio, através da suplementação, poderia possibilitar aumento no consumo da forragem e melhor desempenho animal.

A uréia é muito utilizada como suplemento protéico por ter baixo custo por unidade de nutriente, substituindo parcialmente a proteína verdadeira. Porém, possui uma alta taxa de hidrólise o que se torna um problema pela rápida liberação de amônia em função do acúmulo de $\mathrm{N}_{-} \mathrm{NH}_{3}$ no rumem. A ingestão em excesso pode levar a intoxicação, além de um alto gasto de energia para sua excreção, diminuindo a disponibilidade de energia para o animal (AZEVEDO et al., 2008). No entanto, para diminuir essa alta taxa de degradação foram desenvolvidas fontes de nitrogênio que mantenham os níveis de amônia ruminal constantes ao longo do dia, como a uréia de lenta liberação (FERREIRA et al., 2005). A liberação gradual da amônia no rumem permite aos microorganismos do rumem síntese contínua de proteína celular diminuindo a dependência da reciclagem (NRC, 1996).

Objetivou-se com este trabalho avaliar o efeito da suplementação com uréia de liberação lenta, em substituição parcial da uréia pecuária do sal proteinado, no desempenho de novilhas de corte em pastejo de Tifton-85. 


\section{Material e Métodos}

O experimento foi realizado na Fazenda Dona Elisa, situada no município de Luiziana, noroeste do Estado do Paraná, no período de maio a setembro de 2010. O solo da região é classificado como Latossolo Vermelho Escuro (RAUEN; SÁ; OLIVEIRA, 1996), e o clima é caracterizado como Subtropical Úmido Mesotérmico (SEAB, 2000).

A área destinada ao experimento contava com 11,6 hectares de pastagem de Tifton-85 (Cynodon dactylon) formada há seis anos, corrigida quanto à fertilidade conforme análise prévia de solo. A área foi dividida em quatro piquetes de 2,9 hectares cada, utilizando cerca eletrificada de dois fios, bebedouro com bóia e o saleiro de tambor plástico $(0,15 \mathrm{~m} /$ animal) distribuídos nos piquetes.
Utilizou-se 36 novilhas testers devidamente identificadas, com doze meses de idade e peso médio inicial de $240 \mathrm{~kg}$, provenientes do cruzamento ( $1 / 2$ Red Angus $1 / 2$ Nelore). As novilhas formaram quatro lotes de nove animais, submetidas aos seguintes tratamentos: apenas sal mineralizado (SM); sal proteinado com uréia (SP); sal proteinado com 25\% de substituição da uréia por uréia de lenta degradação (SPLD25); e sal proteinado com 50\% de substituição da uréia por uréia de lenta degradação (SPLD50). A composição do sal proteinado variou apenas pela substituição da uréia pecuária pela uréia encapsulada de lenta degradação (Tabela 1).

Tabela 1. Composição dos suplementos proteinados utilizados na suplementação.

\begin{tabular}{|c|c|c|c|}
\hline \multirow{2}{*}{ Ingredientes } & SP & SPLD25 & SPLD50 \\
\hline & $\%$ & $\%$ & $\%$ \\
\hline Germem de Milho 11\% PB & 36,69 & 36,69 & 36,69 \\
\hline Cloreto de Sódio $39 \% \mathrm{Na}$ & 20,51 & 20,51 & 20,51 \\
\hline Calcário Calcítico $38 \% \mathrm{Ca}$ & 10,52 & 10,52 & 10,52 \\
\hline Fosfato Bicálcico $18 \% \mathrm{P}$ & 8,33 & 8,33 & 8,33 \\
\hline Uréia Pecuária 46\%N & 12,00 & 9,00 & 6,00 \\
\hline Farelo de Soja $46 \% \mathrm{~PB}$ & 7,6283 & 7,6283 & 7,6283 \\
\hline Uréia Encapsulada $46 \% \mathrm{~N}$ & - & 3,00 & 6,00 \\
\hline Filtrado de Enxofre $70 \% \mathrm{~S}$ & 2,85 & 2,85 & 2,85 \\
\hline Óxido de Magnésio 53\%Mg & 0,94 & 0,94 & 0,94 \\
\hline Sulfato de Manganês $31 \% \mathrm{Mn}$ & 0,10 & 0,10 & 0,10 \\
\hline Sulfato de Zinco $35 \% \mathrm{Zn}$ & 0,2857 & 0,2857 & 0,2857 \\
\hline Sulfato de Cobre $24 \% \mathrm{Cu}$ & 0,1042 & 0,1042 & 0,1042 \\
\hline Sulfato de Cobalto $20 \% \mathrm{Co}$ & 0,0075 & 0,0075 & 0,0075 \\
\hline Iodato de Cálcio $62 \% \mathrm{I}$ & 0,0032 & 0,0032 & 0,0032 \\
\hline Selenito de Sódio $45 \% \mathrm{Se}$ & 0,0011 & 0,0011 & 0,0011 \\
\hline Flavorizante & 0,0300 & 0,0300 & 0,0300 \\
\hline TOTAL & 100 & 100 & 100 \\
\hline
\end{tabular}

Fonte: Elaboração dos autores. 
O método de pastejo adotado foi de lotação intermitente com carga variável. A massa de forragem foi estimada a cada 28 dias, conforme metodologia da dupla amostragem descrita por Wilm, Costello e Kliplle (1944), usando a equação proposta por Gardner (1986). Após cada coleta uma amostra composta de cada tratamento foi levada a estufa de circulação forçada de ar com temperatura próxima de $55{ }^{\circ} \mathrm{C}$, por 72 horas ou peso constante e determinados os valores de matéria seca da pastagem, para os cálculos de massa de forragem e estimativas das taxas de lotação nos períodos avaliados.

A taxa de acúmulo diário (TAD) da pastagem foi calculada com a utilização de duas gaiolas de exclusão por piquete, utilizando à seguinte equação:

$$
T A D_{j}=\frac{\left(G_{i}-F_{i-1}\right)}{n}
$$

Em que:

$\mathrm{TAD}$ = taxa de acúmulo diária no período, em $\mathrm{kg}$ $\mathrm{MS} / \mathrm{ha} / \mathrm{dia}$;

$\mathrm{G}_{\mathrm{i}}=$ massa de forragem dentro da gaiola no instante i, em kg MS/ha;

$\mathrm{F}_{\mathrm{i}}=$ massa de forragem fora da gaiola no instante i-1, em kg MS/ha;

$\mathrm{n}=$ número de dias do período $\mathrm{j}$.

A taxa de lotação (TL) por piquete foi calculada considerando a unidade animal (UA) como sendo $450 \mathrm{~kg}$ de $\mathrm{PV}$, dividindo-se a carga animal do piquete pelo valor de $450 \mathrm{~kg}$.

A oferta de forragem utilizada para o ajuste da carga animal, preconizando um valor de $12 \mathrm{~kg}$ de $\mathrm{MS} / 100 \mathrm{~kg}$ de PV, foi estimada de acordo com a seguinte equação:

$$
O F=\frac{[M F D+(T A D \times 28)] / 28 \times 100}{C A}
$$

Em que:

$\mathrm{OF}=$ oferta de forragem, em kg MS/dia/100 kg PV;

$\mathrm{MFD}=$ massa de forragem em $\mathrm{kg} \mathrm{MS} / \mathrm{dia} / \mathrm{ha}$;

$\mathrm{TAD}=$ taxa de acúmulo diário, em $\mathrm{kg} \mathrm{MS} / \mathrm{dia} / \mathrm{ha}$;

$\mathrm{CA}=$ carga animal, em $\mathrm{kg} / \mathrm{ha}$.

Os animais foram pesados no período da manhã, com intervalos de 28 dias sendo que as novilhas foram submetidas a jejum de sólidos e líquidos de aproximadamente 14 horas antes de cada pesagem. O ganho de peso médio diário (GMD) foi obtido pela diferença entre o peso final e inicial dos animais, dividido pelo número de dias do intervalo em cada período experimental. Com os valores do GMD foi calculado o ganho por área através do produto do valor do GMD pelo número de animais por hectare e dias de ocupação.

O fornecimento do suplemento era realizado a cada três dias, onde um tambor de plástico vedado de 200 litros permanecia em cada piquete com pelo menos um saco de sal de $40 \mathrm{Kg}$ de seu respectivo tratamento, para que os funcionários conferissem diariamente a disponibilidade do mesmo no cocho. A cada 28 dias era realizada a pesagem do sal que restava no cocho e no saco para estimativa do consumo do mesmo pelos animais no período e dividindo-se o consumo total pelo número de dias do período, encontrou-se o consumo diário por animal.

O delineamento experimental foi inteiramente casualizado, sendo que os resultados obtidos foram submetidos à análise de variância, de acordo com o seguinte modelo matemático:

$$
\text { Yijk }=\mu+\mathrm{Ti}+\mathrm{Pk}+\text { eijk, em que: }
$$

Yijk = valor observado, relativo à observação $\mathrm{j}$, recebendo o tratamento i no período $\mathrm{k}$;

$\mu=$ constante geral;

$\mathrm{Ti}=$ efeito do tratamento $\mathrm{i}$, com i variando de 1 a 4;

$\mathrm{Pk}=$ efeito do período $\mathrm{k}$, com $\mathrm{k}$ variando de 1 a 4 ;

eijk = erro aleatório inerente a cada observação. 
Para comparação entre médias, foi utilizado o teste Tukey a 5\% e as análises foram realizadas através do programa estatístico ASSISTAT (SILVA; AZEVEDO, 2009).

\section{Resultados e Discussão}

No primeiro período (21/05 a 18/06) de avaliação a massa de forragem (MF) foi superior devido à pastagem estar diferida por um período que antecedeu a entrada dos animais, tendo o primeiro e o segundo período apresentado a maior massa de forragem $(\mathrm{P}<0,05)$ diferindo em relação ao terceiro e quarto períodos experimentais. Entretanto, não foram observadas diferenças para a oferta de forragem que foi em média durante os 112 dias de experimento de $12,3 \mathrm{~kg} \mathrm{MS} / \mathrm{ha} / 100 \mathrm{~kg}$ de PV, muito próximo ao preconizado no trabalho, evidenciando que a oferta não influenciou no desempenho dos animais (Tabela 2). Segundo Corsi e Martha Júnior (1998), a massa de forragem ideal para pastejo do gênero Cynodon é de $2500 \mathrm{~kg}$ de MS/ha, sendo a média da massa de forragem próxima à recomendada durante o período experimental (2573 kg de MS/ha), tendo diminuído nos últimos períodos em consequência da baixa taxa de acúmulo encontrada, entretanto as ofertas de forragem foram constantes, evidenciando o manejo adequado a que o pasto foi submetido.

Tabela 2. Massa forragem (MF), taxa de acumulo diário (TAD) e oferta de forragem (OF) de Tifton 85 durante o período de maio a setembro de 2010 .

\begin{tabular}{lcccccc}
\hline \multicolumn{1}{c}{ Variáveis } & $21 / 05 \mathrm{a} 18 / 06$ & $18 / 06 \mathrm{a} 16 / 07$ & $16 / 07 \mathrm{a} 12 / 08$ & $12 / 08 \mathrm{a} \mathrm{09/09}$ & Media & $\mathrm{CV}(\%)$ \\
\hline $\begin{array}{l}\text { MF } \\
\text { (kgMS/ha) }\end{array}$ & $3255 \mathrm{a}$ & $2940 \mathrm{a}$ & $2393 \mathrm{ab}$ & $1737 \mathrm{~b}$ & 2573 & 13,03 \\
$\begin{array}{l}\text { TAD } \\
\text { (KgMS/ha/dia) }\end{array}$ & 0,84 & 17,86 & 16,97 & 27,86 & 15,88 & 101,3 \\
$\begin{array}{l}\text { OF } \\
(\mathrm{KgMS} / 100 \mathrm{KgPV})\end{array}$ & 12,37 & 13,64 & 12,13 & 11,07 & 12,3 & 9,45 \\
\hline
\end{tabular}

*Letras distintas na linha diferem estatisticamente a 5\% de probabilidade pelo teste de Tukey. CV(\%): coeficiente de variação . Fonte: Elaboração dos autores.

Não foram observadas diferenças $(\mathrm{P}>0,05)$ para taxa de acúmulo diário (TAD) para períodos (Tabela 2), com uma TAD média de 15,88 kg MS/ha. Para esta variável foi observado um elevado coeficiente de variação, consequência da grande variação observada durante o corte de cada uma das gaiolas de exclusão, pois no período em que o trabalho foi conduzido a taxa de crescimento para Tifton 85 é baixa pelas condições climáticas da região, o que não favorece seu desenvolvimento neste período. Da mesma forma, os resultados obtidos por Prohmann et al. (2004), que trabalhando com pastagem de Coastcross na mesma região, no período de junho a outubro observaram TAD abaixo do presente estudo
(9,2 kg de MS ha). Entretanto, observa-se que para o último período de avaliação, quando se aproxima da primavera, a taxa de crescimento da forragem começa a se comportar de maneira diferente, evidenciando que as condições climáticas para esta espécie melhoram já no final de agosto.

Assim como, encontrado para os períodos, a oferta de forragem para os tratamentos (Tabela 3) não apresentou diferença $(P>0,05)$, ficando $o$ valor dentro do preconizado para o experimento (12 kg MS/ha/100kgPV) indicando que a forragem encontrava-se uniformemente distribuída em todos os tratamentos e seus elevados valores possibilitam uma seleção das partes mais nutritivas da pastagem pelos animais. 
Tabela 3. Média da massa de forragem (MF), Oferta de forragem (OF), para os tratamentos sal mineralizado (SM), sal proteinado com uréia (SP), sal proteinado com $25 \%$ de uréia de lenta degradação (SPLD25) e sal proteinado com $50 \%$ de uréia de lenta degradação (SPLD50) para pastagem de Tifton 85 no período de maio a setembro de 2010.

\begin{tabular}{lcccccc}
\hline \multirow{2}{*}{ Variáveis } & \multicolumn{4}{c}{ Tratamentos } & \multirow{2}{*}{ Média } & \multirow{2}{*}{ CV(\%) } \\
\cline { 2 - 5 } & SM & SP & SPLD25 & SPLD50 & & \\
\hline MF (kgMS/ha) & 3171 & 2406 & 2325 & 2422 & 2581 & 26,87 \\
OF (KgMS/100 kgPV) & 12,08 & 11,43 & 12,9 & 12,43 & 12,21 & 25,73 \\
\hline
\end{tabular}

*Letras distintas na linha diferem estatisticamente a $5 \%$ de probabilidade pelo teste de Tukey. $\mathrm{CV}(\%)$ : coeficiente de variação.

Fonte: Elaboração dos autores.

Os ganhos médios diários (Tabela 4) não apresentaram diferenças para as formas de suplementações $(\mathrm{P}>0,05)$. Isto se deve ao fato da alta oferta de forragem disponibilizada aos animais, possibilitando a seleção de partes mais nutritivas da planta, pois gramíneas do gênero Cynodon como a Tifton 85 possuem teores protéicos elevados mesmo em períodos críticos, como por exemplo, no inverno, conforme encontrado por Paris et al. (2008) para as lâminas foliares da grama Coastcross, obtendo valores de 18\% de PB. Moreira et al. (2008) também não observaram diferença entre as suplementações com sal mineral e sal mineral proteinado para bezerros mantidos em capim Mombaça durante o inverno.

Em outras situações, onde a espécie utilizada possui baixos teores de proteína a suplementação protéica produz respostas positivas para o ganho de peso, pois supre a necessidade de nitrogênio das bactérias ruminais. De acordo com Van Soest (1994) valores inferiores a 7\% de PB limitam a fermentação ruminal pela menor síntese de bactérias, sendo nestes casos o fornecimento de um aporte de proteína não verdadeira benéfico ao sistema produtivo. Entretanto para o presente estudo não verificou-se efeito da uréia em sua forma normal ou protegida, principalmente devido a qualidade nutricional elevada da forrageira em estudo. Gonçalves et al. (2003) destacam a Tifton-85 pela elevada digestibilidade in vitro da matéria seca e altas taxas de crescimento, sendo recomendado sistemas com elevada produtividade.

Segundo Campos Neto et al. (2003), a liberação rápida da amônia é o fator limitante do uso de nitrogênio não protéico, pois se houver deficiência de energia na dieta do animal, situação esta que ocorre com frequência no período de inverno com as pastagens tropicais, a amônia livre no rúmen não será utilizada pelos microrganismos para formação das proteínas microbianas. Neste caso, a amônia (NH3) será absorvida pelas papilas ruminais, sendo metabolizada no fígado com dispêndio de energia, o que reflete negativamente sobre o desempenho dos animais. Moreira et al. (2003) avaliaram a suplementação com uréia em comparação ao sal mineral, sobre o desempenho de 60 novilhos mestiços com peso médio de $299 \mathrm{~kg}$, mantidos em pastagem de estrela roxa, no final do verão, e também não observaram diferenças $(\mathrm{P}>0,05)$ para ganho de peso. 
Tabela 4. Ganho médio diário (GMD), ganho de peso corporal por hectare (GPV/ha), consumo de sal (CS) e taxa de lotação para os tratamentos sal mineralizado (SM), sal proteinado com uréia (SP), sal proteinado com $25 \%$ de uréia de lenta degradação (SPLD25) e sal proteinado com 50\% de uréia de lenta degradação (SPLD50) em pastagem de Tifton 85 no período de maio a setembro de 2010.

\begin{tabular}{|c|c|c|c|c|c|}
\hline \multirow{3}{*}{ Períodos } & \multicolumn{4}{|c|}{ Tratamentos } & \multirow{3}{*}{ Média } \\
\hline & SM & SP & SPLD25 & SPLD50 & \\
\hline & \multicolumn{4}{|c|}{ GMD- kg/dia } & \\
\hline $21 / 05$ a $18 / 06$ & 0,099 & 0,067 & 0,071 & 0,079 & $0,079 \mathrm{~b}$ \\
\hline $18 / 06$ a $16 / 07$ & $-0,257$ & $-0,067$ & $-0,059$ & $-0,095$ & $-0,120 \mathrm{c}$ \\
\hline $16 / 07$ a $13 / 08$ & 0,123 & $-0,047$ & $-0,031$ & 0,047 & $0,022 \mathrm{~b}$ \\
\hline $13 / 08$ a $10 / 09$ & 0,297 & 0,285 & 0,234 & 0,269 & $0,271 \mathrm{a}$ \\
\hline Média & 0,065 & 0,059 & 0,053 & 0,075 & \\
\hline Períodos & \multicolumn{4}{|c|}{ GPV/ha - kg } & Média \\
\hline $21 / 05$ a $18 / 06$ & 41,67 & 22,67 & 18,00 & 20,00 & $25,583 \mathrm{a}$ \\
\hline $18 / 06$ a $16 / 07$ & $-79,44$ & $-17,00$ & $-16,67$ & $-29,33$ & $-35,611 b$ \\
\hline $16 / 07$ a $13 / 08$ & 18,00 & $-16,67$ & $-8,00$ & $-8,00$ & $-3,667 a b$ \\
\hline $13 / 08$ a $10 / 09$ & 20,00 & $-29,33$ & 12,00 & 68,00 & $17,667 \mathrm{a}$ \\
\hline Média & 0,056 & $-10,083$ & 1,333 & 12,667 & \\
\hline Períodos & \multicolumn{4}{|c|}{$\mathrm{CS}-\mathrm{kg} / \mathrm{dia}$} & Média \\
\hline $21 / 05$ a $18 / 06$ & 0,085 & 0,188 & 0,140 & 0,121 & 0,133 \\
\hline $18 / 06$ a $16 / 07$ & 0,115 & 0,202 & 0,327 & 0,307 & 0,237 \\
\hline $16 / 07$ a $13 / 08$ & 0,089 & 0,129 & 0,143 & 0,143 & 0,126 \\
\hline $13 / 08$ a $10 / 09$ & 0,138 & 0,211 & 0,121 & 0,214 & 0,171 \\
\hline Média & 0,106 & 0,182 & 0,182 & 0,196 & \\
\hline Períodos & \multicolumn{4}{|c|}{ Taxa de Lotação - UA/ha } & Média \\
\hline $21 / 05$ a $18 / 06$ & 3,08 & 2,63 & 2,19 & 2,14 & $2,51 \mathrm{a}$ \\
\hline $18 / 06$ a $16 / 07$ & 2,44 & 2,16 & 1,87 & 1,89 & $2,09 \mathrm{ab}$ \\
\hline $16 / 07$ a $13 / 08$ & 1,87 & 1,85 & 1,83 & 1,73 & $1,82 \mathrm{~b}$ \\
\hline $13 / 08$ a $10 / 09$ & 1,81 & 1,99 & 2,16 & 2,02 & $1,99 \mathrm{ab}$ \\
\hline Média & 2,30 & 2,16 & 2,01 & 1,94 & \\
\hline
\end{tabular}

*Letras minúsculas distintas na coluna e maiúsculas na linha diferem estatisticamente a 5\% de probabilidade pelo teste de Tukey. Fonte: Elaboração dos autores.

Entretanto, para os períodos experimentais houve efeito significativo $(\mathrm{P}<0,05)$ no ganho de peso independentemente das suplementações testadas (Tabela 4), principalmente devido a variação da qualidade da forragem. No último período, correspondente ao final de agosto e início de setembro, os animais apresentaram os maiores ganhos de peso (271gramas/animal/dia), possivelmente em razão do rebrote da pastagem, pois neste mesmo período a taxa de acúmulo diário foi de $27,86 \mathrm{~kg}$ de $\mathrm{MS} / \mathrm{ha}$.

O período mais crítico foi junho e julho com perda de peso para todos os tratamentos, entretanto mais acentuado para o suplementado apenas com sal mineral, aproximadamente 200 gramas por dia de perdas, mas sem diferenças $(\mathrm{P}>0,05)$ para os demais. Este comportamento no desempenho pode estar relacionado ao menor consumo de forragem pelos animais, em virtude dos elevados teores de carboidratos fibrosos encontrados em pastagens que apresentam pouco ou nenhum perfilhamento em alguns períodos desse ciclo, disponibilizando assim aos animais material mais velho com menor qualidade. Segundo Malafaia et al. (2003), a qualidade das pastagens tropicais durante a estação fria é menor devido os bovinos se alimentarem das 
sobras de forragens oriundas da primavera e verão, que apresentam elevados teores de fibra.

Os resultados observados para desempenho animal evidenciam que apesar de apresentar oferta de forragem suficiente, com teores de PB adequada, a planta apresenta menores teores de digestibilidade e energia, limitando o crescimento bacteriano e tornando o nitrogênio não protéico (uréia) fornecido ineficiente para aumentos em ganho de peso. A uréia apresenta rápida transformação em amônia não estando associado à velocidade de degradação dos carboidratos fibrosos da pastagem, e, nem mesmo a uréia encapsulada que tem como objetivo ser liberada de forma mais lenta no rúmen foi suficiente para proporcionar maior desempenho aos animais.

$\mathrm{Na}$ Tabela 4, ao se observar o ganho de peso corporal por hectare (GPV/ha), verifica-se que este também não apresentou diferença $(\mathrm{P}>0,05)$ para os tratamentos testados, somente para os períodos, sendo os maiores GPV/ha verificados no primeiro e no último período. Consequência da maior qualidade da forragem nestes períodos, pois nos meses de maio (outono) e setembro (primavera) as condições climáticas favoráveis permitem maiores taxas de crescimento e surgimento de folhas novas aumentando a qualidade nutricional da dieta. No presente trabalho a oferta disponibilizada aos animais foi elevada (12 kg MS/ha/100kgPV), possibilitando a seleção de partes mais nutritivas e assim maiores ganhos por área para estes períodos. Da mesma forma, Moreira at al. (2004) e Moreira et al. (2008), não verificaram efeito da suplementação com sal proteinado para novilhos Nelore, porém com uma média de GPV/ha superior à do presente trabalho $(33,66 \mathrm{~kg} / \mathrm{ha})$.

Outra variável responsável pelo desempenho semelhante entre os tratamentos foi o consumo de sal que não apresentou diferença $(\mathrm{P}<0,05)$, quando comparado para tratamento e períodos (Tabela 4). A média de consumo de sal mineral nos períodos foi de $106 \mathrm{~g} /$ animal/dia, e para os tratamentos SP, SPLD25 e SPLD50 foram de 182, 182 e 196 g/animal/dia, respectivamente. Esta diferença entre sal mineral e os produtos com fontes protéicas se deve a sua composição, principalmente ao cloreto de sódio que limita um consumo maior do produto. Entretanto deve-se destacar o consumo no segundo período de avaliação, correspondente aos meses de junho e julho, onde os animais apresentaram os menores desempenhos, o consumo de sal foi o mais elevado, e mesmo assim não foram observadas diferenças nos desempenhos dos animais, evidenciado que a disponibilidade de energia prontamente disponível para as bactérias ruminais não era suficiente para estas aproveitarem a amônia liberada no rúmen, mesmo em velocidades menores.

O aporte de PB via sal proteinado pode ser estimado, pois o produto formulado continha em torno de $42 \%$ de $\mathrm{PB}$, e se for considerarado um consumo total de matéria seca de $5 \mathrm{~kg} / \mathrm{animal} /$ dia e destes 187 gramas são sal proteinado, tem-se um aumento de $1,57 \%$ no teor protéico da dieta total quando do fornecimento do sal proteinado. Valores estes não suficientes para promoverem maiores ganhos, pois a uréia que é o maior constituinte do produto não será transformada em energia podendo ser prejudicial ao sistema em virtude do excesso de amônia presente no rúmen, esta deverá ser eliminada para não provocar uma intoxicação ao animal e, para isto, há maior gasto de energia para as células hepáticas converterem em uréia o aporte excessivo de amônia (OLDHAM, 1984).

Knorr et al. (2005) verificaram consumos médios de 391 gramas/dia/animal de sal proteinado com uréia e de 38 gramas/dia/animal de sal mineral (peso corporal médio de $264 \mathrm{~kg}$ ). Já Moreira et al. (2003), encontraram consumos médio de 189 e 76 gramas/dia/animal de sal proteinado e sal mineral respectivamente, para novilhos mestiços com peso médio de $299 \mathrm{~kg}$ de peso corporal. O consumo de sal foi inferior ao do presente estudo, entretanto, o de sal proteinado foi semelhante ao obtido neste trabalho, evidenciando que para pastagens do gênero Cynodon (Estrela africana, Coastcross e Tifton) quando bem manejadas, com ofertas de 
forragem adequadas, o desempenho dos animais não é influenciado pela suplementação de sal proteinado na dieta. Talvez se os produtos contivessem menores teores de nitrogênio não protéico e mais proteína verdadeira, os resultados para o produto poderiam ser diferentes, possibilitando um maior aproveitamento da fibra que apresenta velocidade de degradação lenta. Esta lenta degradação da fibra não disponibiliza esqueletos de carbono na velocidade adequada para os microorganismos aproveitarem a amônia, sendo o sincronismo entre energia e proteína degradavel no rúmen fundamental para maior síntese de proteína microbiana e consequente maior desempenho animal (MIZUBUTI, et al., 2007).

Não foi observado efeito $(\mathrm{P}>0,05)$ para os tratamentos quanto a taxa de lotação, porém, houve diferença entre os períodos $(\mathrm{P}<0,05)$, em virtude da maior carga animal necessária para atingir a oferta de forragem estipulada para o manejo da pastagem, pois a pastagem apresentava uma massa maior no primeiro período, consequência da vedação antes do início do experimento. Entretanto os valores médios obtidos para lotação $(2,1 \mathrm{UA} / \mathrm{ha})$ foram satisfatórios para o período em questão (maio a setembro) em que as espécies tropicais apresentam baixa produtividade pelas condições climáticas desfavoráveis ao seu crescimento conforme observado pelos dados de taxa de acúmulo. Prohmann et al. (2004) avaliando a suplementação de bovinos em pastagens de Coastcross no inverno encontraram valores semelhantes de taxa de lotação (2,05 UA/ha), porém não verificaram diferença entre os períodos.

Azevedo et al. (2008) destacam o uso da uréia pelo seu baixo custo por unidade de nutriente, podendo substituir a proteína verdadeira, parcialmente, como forma de reduzir o custo de produção. Entretanto quando se trabalha com pastagem de elevado valor nutritivo como a Tifton-85 e oferta de forragem não limitante ao consumo, não se observa diferenças no ganho de peso dos animais suplementados com sal proteinado, consequência do não aproveitamento de forma eficiênte da amônia pelos microorganismos ruminais devido ao não sinergismo entre energia e protéina, sendo indicada nessas situações somente a suplementação mineral pelo menor custo.

\section{Conclusões}

A suplementação de novilhas de corte em pastagens de Tifton 85 no período de final de outono e inverno, com diferentes níveis de substituição de uréia comum por uréia de lenta degradação, não resultou em acréscimo no ganho médio diário e por área, sendo recomendada nesta situação a utilização de sal mineralizado, pois possui um custo inferior aos demais.

\section{Agradecimentos}

A Fundação Araucária pelo apoio financeiro concedido para realização do presente trabalho.

\section{Referências}

AZEVEDO, E. B.; PATIÑO, H. O.; SILVEIRA, A. L. F.; LÓPEZ, J.; BRÜNING, G.; KOZLOSKI, G. V. Incorporação de uréia encapsulada em suplementos protéicos fornecidos para novilhos alimentados com feno de baixa qualidade. Ciência Rural, Santa Maria, v. 38, n. 5, p. 1381-1387, 2008.

CAMPOS NETO, O. C.; SCALZO, A. L.; CAMPANHA, F. B.; ABRAHÃO, D. H. C. Uréia de liberação lenta: avaliação química e biológica. Revista Científica Eletrônica de Medicina Veterinária, Garça, v. 1, n. 1, p. 28-30, 2003.

CORSI, M.; MARTHA JÚNIOR, G. B. Manejo de pastagens para produção de carne e leite. In: SIMPÓSIO SOBRE MANEJO DA PASTAGEM, 15., 1998, Piracicaba. Anais... Piracicaba: FEALQ, 1998. p. 296.

EUCLIDES, V. P. B.; EUCLIDES FILHO, K.; COSTA, F. P.; FIGUEIREDO, G. R. Desempenho de novilhos F1s angus-nelore em pastagens de Brachiária decumbens submetidos a diferentes regimes alimentares. Revista Brasileira de Zootecnia, Viçosa, MG, v. 30, n. 2, p. 470481, 2001. 
FERREIRA, R. N.; OLIVEIRA, E. R.; ORSINE, G. F.; PAULA, A. A.; OLIVEIRA, L. G.; BITTENCOURT, A. R.; SOUZA, S. N. Liberação de nitrogênio amoniacal no rumen com o uso de uréia encapsulada com polímero (Optigen 1200 Alltec). In: REUNIÃO ANUAL DA SOCIEDADE BRASILEIRA DE ZOOTECNIA, 42., 2005, Goiânia, GO. Anais... Goiânia: Sociedade Brasileira de Zootecnia, 2005. CD-ROOM.

GARDNER, A. L. Técnicas de pesquisa em pastagens e aplicabilidade de resultados em sistemas de produção. Brasília: IICA/EMBRAPA-CNPGL, 1986. 197 p. (Série publicações miscelâneas, 634).

GONÇALVES, G. D.; SANTOS, G. T.; JOBIM, C. C.; DAMASCENO, J. C.; CECATO, U.; BRANCO, A. F. Determinação do consumo, digestibilidade e frações protéicas e de carboidratos do feno de tifton 85 em diferentes idades de corte. Revista Brasileira de Zootecnia, Viçosa, MG, v. 32, n. 4, p. 804-813, 2003.

KNORR, M.; PATINO, H. O.; SILVEIRA, A. L. F.; MÜHLBACH, P. R. F.; MALLMANN, G. M.; MEDEIROS, F. S. Desempenho de novilhos suplementados com sais proteinados em pastagem nativa. Pesquisa Agropecuária Brasileira, Brasília, v. 40, n. 8, p. 783-788, 2005.

MALAFAIA, P.; CABRAL, L. S.; VIEIRA, R. A. M.; COSTA, R.; CARLOS, A. B. Suplementação protéicoenergética para bovinos criados em pastagens: aspectos teóricos e principais resultados publicados no Brasil. Livestock Research for Rural Development, v. 15, n. 12, p. 33, 2003.

MIZUBUTI, I. Y.; MOREIRA, F. B.; RIBEIRO, E. L. de A.; PEREIRA, E. L.; ROCHA, M. A.; SILVA FILHO, M. F. Degradabilidade in situ da matéria seca e da proteína bruta do farelo de arroz, farelo de trigo, grão de milho e grão de aveia. Acta Scientiarum Animal Sciences, Maringá, v. 29, n. 2, p. 187-193, 2007.

MOREIRA, F. B.; MIZUBUTI, I. Y.; PRADO, I. N.; MATSUSHITA, M.; MATSUBARA, M. T.; DOGNANI, R. Suplementação com sal mineral proteinado para bezerros mantidos em pastagem de capim Mombaça, no inverno. Semina: Ciências Agrárias, Londrina, v. 29, n. 1, p. 203-210, 2008.

MOREIRA, F. B.; PRADO, I. N.; CECATO, U.; SOUZA, N. E.; IWAYAMA, P. T. Suplementação com sal mineral proteinado para bovinos de corte mantidos em pastagem de estrela roxa no final do verão. Acta Scientiarum Animal Sciences, Maringá, v. 25, n. 1, p. 185-191, 2003.
MOREIRA, F. B.; PRADO, I. N.; CECATO, U.; ZEOULA, L. M.; WADA, F. Y.; TORII, M. S. Níveis de suplementação com sal mineral proteinado para novilhos nelore terminados em pastagem no período de baixa produção forrageira. Revista Brasileira de Zootecnia, Viçosa, MG, v. 33, n. 6, p. 1814-1821, 2004.

NATIONAL RESEARCH COUNCIL - NRC. Nutrient requirements of beef cattle. 6. ed. Washington, DC: National Academy, 1996. 242 p.

OLDHAM, J. D. Protein - energy relationships in dairy cows. Journal of Dairy Science, Madison, v. 67, n. 5, p. 1090-1114, 1984.

PARIS, W.; CECATO, U.; SANTOS, G. T.; BARBEIRO, L.; AVANZZO, L.; LIMÃO, V. Produção e qualidade de massa de forragem nos estratos da cultivar coastcross-1 consorciada com Arachis pintoi com e sem adubação nitrogenada. Acta Scientiarum Animal Sciences, Maringá, v. 30, n. 2, p. 135-143, 2008.

PROHMANN, P. E. F.; BRANCO, A. F.; CECATO, U.; JOBIM, C. C.; GUIMARÃES, K.; FERREIRA, R. A. Suplementação de bovinos em pastagem de Coastcross (Cynodon dactylon (L.) Pers) no inverno. Revista Brasileira de Zootecnia, Viçosa, MG, v. 33, n. 3, p. 801810, 2004.

RAUEN, M. J.; SÁ, J. C. M.; OLIVEIRA, E. F. Forragicultura no Paraná. Londrina: Alda Lúcia Gomes Monteiro e Outros, 1996. 305 p.

SECRETARIA DA AGRICULTURA E DO ABASTECIMENTO DO ESTADO DO PARANÁ SEAB. "Paraná cidade: Luiziana". 2000. Disponível em: <http://www.paranacidade.org.br/base/municipio. asp $>$. Acesso em: 12 jun. 2010.

SILVA, F. A. S.; AZEVEDO, C. A. V. Principal components analysis in the software assistatstatistical attendance. In: WORLD CONGRESS ON COMPUTERS IN AGRICULTURE, 7., 2009, Reno-NVUSA. Proceedings... Reno-NV-USA: American Society of Agricultural and Biological Engineers, 2009.

VAN SOEST, P. J. Nutritional ecology of the ruminant. 2. ed. New York: Cornell University Press, 1994. 476 p.

WILM, H. G.; COSTEllo, D. F.; KLIPLlE, G. E. Estimating forage yield by the double sampling method. Journal of the American Society of Agronomy, Madison, v. 36, n. 1, p. 194-203, 1944. 